\title{
Extra-gonadal sites of estrogen biosynthesis and function
}

\author{
Radwa Barakat ${ }^{1,2}$, Oliver Oakley ${ }^{3}$, Heehyen $\mathrm{Kim}^{4}$, Jooyoung $\mathrm{Jin}^{4} \mathcal{E}^{\mathrm{E}}$ CheMyong Jay $\mathrm{Ko}^{1, *}$ \\ ${ }^{1}$ Department of Comparative Biosciences, University of Illinois at Urbana-Champaign, Illinois 61802, Unites States, ${ }^{2}$ Department of \\ Toxicology, Faculty of Veterinary Medicine, Benha University, Benha 13518, Egypt, ${ }^{3}$ Department of Biology, College of Arts and Sciences, \\ Eastern Kentucky University, Kentucky 40475, United States, ${ }^{4}$ Department of Agricultural Biotechnology, Seoul National University, Seoul \\ 08826, Korea
}

\begin{abstract}
Estrogens are the key hormones regulating the development and function of reproductive organs in all vertebrates. Recent evidence indicates that estrogens play important roles in the immune system, cancer development, and other critical biological processes related to human well-being. Obviously, the gonads (ovary and testis) are the primary sites of estrogen synthesis, but estrogens synthesized in extra- gonadal sites play an equally important role in controlling biological activities. Understanding non-gonadal sites of estrogen synthesis and function is crucial and will lead to therapeutic interventions targeting estrogen signaling in disease prevention and treatment. Developing a rationale targeting strategy remains challenging because knowledge of extra-gonadal biosynthesis of estrogens, and the mechanism by which estrogen activity is exerted, is very limited. In this review, we will summarize recent discoveries of extra-gonadal sites of estrogen biosynthesis and their local functions and discuss the significance of the most recent novel discovery of intestinal estrogen biosynthesis. [BMB Reports 2016; 49(9): 488-496]
\end{abstract}

\section{INTRODUCTION}

Estrogens are a class of steroid hormones that regulate the development and function of male and female reproductive organs. In the ovary, estrogen synthesis begins in theca cells with androgen synthesis and ends with conversion of androgens to estrogens in granulosa cells by the enzyme aromatase. In the male gonad, estrogens are synthesized in the Leydig cells, Sertoli cells, and mature spermatocytes (1). Like other steroid hormones, estrogens enter passively into the cells and bind to the estrogen receptors, which then regulate the transcription of downstream estrogen-responsive genes. Among the number of different forms of estrogens, $17 \beta$-estradiol

*Corresponding author. Tel: +217-333-9362; Fax: +217-244-1652; E-mail: jayko@illinois.edu

http://dx.doi.org/10.5483/BMBRep.2016.49.9.141

Received 2 August 2016

Keywords: Estrogen, Estrogen receptor, Extra-gonadal (estradiol) is the most common and potent form of estrogen in mammals. Estradiol is also produced in a number of extragonadal organs, including the adrenal glands, brain, adipose tissue, skin, pancreas (2-4), and other sites yet to be identified. The discoveries of extra-gonadal sites of estradiol synthesis greatly expands our knowledge of the novel roles of estrogens beyond the reproductive system.

\section{EXTRA-GONADAL SITES OF ESTROGEN SYNTHESIS AND ITS LOCAL ROLES}

The first discovery of extra-gonadal estrogen synthesis was made in 1974 by Hemsell and his colleagues when they made an unexpected observation that androgens were converted to estrogens in adipose tissue (5). Since then, a number of other extra-gonadal sites of estrogen synthesis have been discovered. Adipose tissues are considered to be the major source of circulating estrogen after the gonads in both men and women, and the contribution made by the adipose tissues to the total circulating estrogens increases with advancing age (5). The chemical structure and biological activity of the estrogens synthesized in the extra-gonadal sites are not different from those that are produced by the gonads. However, there are unique features that make the extra-gonadal estrogen synthesis differ from the gonadal synthesis. A major difference is in the biochemical pathway of estrogen synthesis. The tissues and cells of the extra-gonadal sites of estrogen synthesis are unable to synthesize $\mathrm{C} 19$ steroids, the precursors of estrogen synthesis, but are able to convert C19 steroids to estrogens, a critical and rate-limiting step mediated by Cyp19 aromatase. Hence, extra-gonadal estrogen synthesis is dependent on an external source of C19 precursors (4) and the level of aromatase expression. Because C19 steroids can be supplied to a local tissue via circulation and are converted to estrogens in any tissue where aromatase is expressed, the presence of aromatase expression in a local tissue confirms extra-gonadal estrogen synthesis. Table 1 lists the peripheral tissues that express aromatase and are therefore able to convert C19 precursors to estrogens. These extra-gonadally synthesized estrogens are thought to act and be metabolized locally, which limits their systemic effects (6). Another unique feature of extra-gonadal estrogen synthesis is that while the total amount

ISSN: 1976-670X (electronic edition)

Copyright (c) 2016 by the The Korean Society for Biochemistry and Molecular Biology

(c) This is an open-access article distributed under the terms of the Creative Commons Attribution Non-Commercial License (http://creativecommons.org/licenses/by-nc/4.0) which permits unrestricted non-commercial use, distribution, and reproduction in any medium, provided the original work is properly cited. 
Table 1. Extra-gonadal sites of estrogen synthesis

\begin{tabular}{|c|c|c|c|c|}
\hline \multirow{2}{*}{ Sites } & \multicolumn{3}{|c|}{ Evidence of $17 \beta$-estradiol synthesis } & \multirow{2}{*}{ References } \\
\hline & Cyp19 mRNA & Cyp19 protein & 17ß-estradiol & \\
\hline Brain & $\begin{array}{l}\text { Astrocyte (rat, mouse, human), } \\
\text { Hippocampus and hypothalamus } \\
\text { (rat, mouse, monkey, human) }\end{array}$ & $\begin{array}{l}\text { Astrocyte (mouse), GnRH (rat), } \\
\text { Dentate gyrus/ pyramidal cell (rat, mouse, } \\
\text { human, monkey), Interneurons (human), } \\
\text { Granular cell (human, monkey), Purkinje } \\
\text { cell (human, mouse), Ependymal } \\
\text { andsubependymal cell (human). }\end{array}$ & Astrocyte (rat, monkey). & $(7-16)$ \\
\hline Fat & $\begin{array}{l}\text { Stromal cell (human), } \\
\text { Adipocyte (human) }\end{array}$ & $\begin{array}{l}\text { Stromal cell (human), Adipocyte, } \\
\text { mesenchymal cell (human) }\end{array}$ & & $(13-16)$ \\
\hline Bone & Osteoblast (human) & Osteoblast (human) & Osteoblast (human) & $(17-19)$ \\
\hline Liver & $\begin{array}{l}\text { HepG2 hepatoma } \\
\text { andhepatocellular carcinoma } \\
\text { (human), Hepatocyte (porcine). }\end{array}$ & $\begin{array}{l}\text { HepG2 hepatoma and hepatocellular } \\
\text { carcinoma (human) }\end{array}$ & $\begin{array}{l}\text { HepG2 hepatoma and } \\
\text { hepatocellular carcinoma } \\
\text { (human) }\end{array}$ & $(20-22)$ \\
\hline Adrenal gland & $\begin{array}{l}\text { Adrenocortical cell } \\
\text { (human, porcine, rat) }\end{array}$ & Adrenocortical cell (human) & Adrenocortical cell (rat) & $(22-24)$ \\
\hline Intestine & Parietal cell (rat) & Parietal cell (rat) & Parietal cell (rat) & (25) \\
\hline Skin & $\begin{array}{l}\text { Fibroblast (human). } \\
\text { Keratinocyte (human). }\end{array}$ & $\begin{array}{l}\text { Fibroblast (chicken, human), } \\
\text { Keratinocyte (human) }\end{array}$ & Fibroblast (chicken) & $(26-28)$ \\
\hline Blood vessel & $\begin{array}{l}\text { Smooth muscle cell } \\
\text { (human, rat, bovine) }\end{array}$ & Smooth muscle cell (human, rat, bovine) & & $(29-31)$ \\
\hline Spleen & T cell (mouse) & T cell (mouse) & & (32) \\
\hline
\end{tabular}

Table 2. Extra-gonadal sites of estrogen receptor expression

\begin{tabular}{|c|c|c|c|c|}
\hline \multirow{2}{*}{ Sites } & \multicolumn{3}{|c|}{ Receptor subtypes } & \multirow{2}{*}{ References } \\
\hline & $\mathrm{ER} \alpha$ & $E R \beta$ & Other receptors & \\
\hline Brain & $\begin{array}{l}\text { Cholinergic neuron (rat), GABAergic } \\
\text { neuron (rat), Pro-opiomelanocortin } \\
\text { neuron (mouse). }\end{array}$ & $\begin{array}{l}\text { GnRH neurons (mouse), Subiculum } \\
\text { neuron (monkey), Ammon's horn } \\
\text { neuron (monkey) }\end{array}$ & $\begin{array}{l}\text { GPER1 (glial cell, rat), } \\
\text { GPER1 (GABAergic neuron, } \\
\text { rat). }\end{array}$ & $(33-37)$ \\
\hline Fat & Adipocyte (human) & Adipocyte (human) & GPER (adipocyte, mouse) & $(38-40)$ \\
\hline Bone & Osteoblast (mouse), Osteocyte (mouse). & $\begin{array}{l}\text { Osteoblast (human), Osteocyte } \\
\text { (human), Osteoclast (rat, human). }\end{array}$ & & $(41-46)$ \\
\hline Liver & Hepatocyte (rat) & & & (25) \\
\hline Blood vessel & $\begin{array}{l}\text { Smooth muscle cell (human), Vascular } \\
\text { endothelial cell (human) }\end{array}$ & Endothelial cell (human) & GPR30 (endothelial cell, rat) & $(47-50)$ \\
\hline Intestine & $\begin{array}{l}\text { Epithelial cell (rat), Parietal cell (rat), } \\
\text { Myenteric neuron (rat) }\end{array}$ & Epithelial cell (rat), Parietal cell (rat) & $\begin{array}{l}\text { GPER (colonic epithelia, } \\
\text { human) }\end{array}$ & $(51,52)$ \\
\hline Skin & $\begin{array}{l}\text { Keratinocyte (human), Mast cell } \\
\text { (human) Sebocyte (human) }\end{array}$ & $\begin{array}{l}\text { Keratinocyte (human), } \\
\text { Mast cell (human) }\end{array}$ & & $(53-55)$ \\
\hline Adrenal gland & Adrenal cortex (rat) & Adrenal cortex (rat) & GPER1 (rat) & (56) \\
\hline Muscle & Satellite cell (rat) & Satellite cell (rat) & & (57) \\
\hline Kidney & Mesangial cells (human, mouse) & Mesangial cells (human, mouse) & & (58) \\
\hline Pancreas & $\beta$-cell (mouse) & $\beta$-cell (mouse) & & $(59,60)$ \\
\hline
\end{tabular}

of estrogen synthesized in each tissue may be small, the local tissue concentrations of estrogens could be high enough to exert biological impact locally. The functional roles of estrogens are mediated mostly by estrogen receptors that are nuclear receptor transcription factors. Therefore, a tissue that expresses one or more estrogen receptors is considered to be a target of estrogenic regulation. Table 2 lists key organs and tissues that express estrogen receptors. 


\section{Adipose tissues}

Adipose tissues, where estradiol stimulates the production of high density lipoprotein cholesterol (HDL) and triglycerides while decreasing LDL production and and fat deposition (61, $62)$, are the most extensively studied sites of extra-gonadal estrogen synthesis. Both male and female aromatase-deficient (Cyp19KO) mice exhibit obesity and dyslipidemia (61, 62), proving that estradiol plays a beneficial role in the lipogenesis. However, an adverse effect of adipose tissue-driven estradiol is also indicated in the pathogenesis of breast cancer. For instance, in a breast with a tumor, adipose tissues proximal to the tumor exhibit higher aromatase activity than those distal to the tumor (63).

\section{Bone}

Aromatase expression in human bone has been demonstrated in osteoblasts, chondrocytes, and fibroblasts (Table 1), where they convert circulating androgens into estrogens (64). In the bone of prepubertal children, the locally synthesized estradiol stimulates epiphyseal maturation during the growth phase (65). However, in both males and females, the massive pubertal increase of estradiol leads to increased apoptosis of chondrocytes in the epiphyseal plate, causing chondrocyte depletion and hence, ossification and growth slow-down (66). In adults, estradiol increases bone formation and mineralization and reduces bone resorption, thus reducing the risk of osteoporosis (64). Therefore, it is not surprising that the incidence of osteoporosis increases in postmenopausal women as their ovaries lose estradiol synthetic capacity.

\section{Skin}

Aromatase expression in the skin occurs mainly in hair follicles and sebaceous glands (67). Glucocorticoids, cAMP analogs, growth factors, and cytokines modulate aromatase expression in these cells and therefore, local estrogene synthesis (68). Estradiol enhances collagen synthesis, increases skin thickness, and stimulates blood flow in the skin. Therefore, in situ estrogen synthesis in the skin is vital for maintaining healthy skin (69). Estradiol also prolongs the anagen phase of the hair cycle and therefore enhances hair growth by increasing the synthesis of essential growth factors stimulating the proliferation of hair follicle cells (70).

\section{Liver}

In the liver, estradiol regulates protein synthesis, including lipoprotein and proteins responsible for blood clotting (factors II, VII, IX, X, plasminogen) (71). Estrogen signaling is also essential in regulating glucose homeostasis, thus improving glucose tolerance and insulin sensitivity (72). Recent research has explored the possibility that postmenopausal women with nonalcoholic fatty liver disease and with long durations of estrogen deficiency could have a higher risk of having severe fibrosis than premenopausal women (73). Estrogen receptor beta $(E R \beta)$ is implicated in mediating the protective role that estradiol plays under pathogenic condition in the liver as it shows potent anti-proliferative and anti-inflammatory properties. As such, chronic disease is linked to elevated ER $\beta$ expression in the liver (74). ER $\beta$ is also known to mediate the anti-tumor action of estrogens in intrahepatic cholangiocarcinoma (75).

\section{Brain}

High levels of estrogen receptors are expressed during brain development. During this period, sex hormones determine apoptosis, neuronal migration, neurogenesis, axonal guidance, and synaptogenesis. Estradiol induces sexual differentiation in the developing brain. Aromatase mRNA expression in the hypothalamus of males peaks before and after birth, inducing sexual differentiation of the brain (76). In the brains of both males and females, estradiol provides a neuroprotective effect. Estradiol's prevention of neurodegeneration in brain tissues is proven in both the Cyp19KO mouse model and the aromatase inhibitor-treated mouse (8). Inhibition or null mutation of aromatase, a key enzyme for estradiol synthesis, results in accelerated neurodegeneration (8). Estradiol effects in the brain also include regulating mood, pain sensitivity, motor control, and cognitive behavior (13-16). Estradiol regulates neuronal metabolism by modulating the expression of metabolic enzymes such as GLUT (glucose-transporter), glycolytic enzyme hexokinase, pyruvate dehydrogenase (PDH), aconitase, and ATP synthase (77).

\section{Adrenal gland}

Estrogens stimulate adrenal cortex growth during development by promoting cell proliferation and enhancing steroidogenic activity by increasing StAR and SF-1 expression in the adrenal gland (30). In the fetal adrenal gland, estradiol and ACTH form as a positive regulatory loop in which estradiol increases ACTH secretion from adrenal cortex while ACTH increase estradiol in the ovary (78).

\section{Pancreas}

Estradiol increases insulin gene expression and insulin content in $\beta$-cells $(59,79)$, increases $\beta$-cell proliferation during pancreatic development and recovery from injury (80), and prevents apoptosis of $\beta$-cells upon inflammatory insult (59) via $E R \alpha$ - and ER $\beta$-mediated pathways.

\section{Others}

In the blood vessel, estradiol positively impacts vascular function by preventing the oxidation of LDL cholesterol, stimulating nitric oxide synthesis and release, and inhibiting fibroblast transition to myofibroblast, preventing cardiac fibrosis (81-83) and atherosclerosis development. In the muscle, estradiol increases muscle mass and strength, alleviating disuse-induced muscle atrophy and promoting regrowth after reloading. It also stimulates muscle repair by stimulating satellite cell proliferation $(84,85)$. Estradiol replacement on ovariectomized mice shows that estradiol can reduce stiffness 
in muscle as well as stimulate muscle regeneration (39). In the kidney, estradiol has a role of protecting kidney functions during progressive glomerulosclerosis in the female rat remnant kidney model (86). In the intestine, to maintain the intestinal epithelium, estrogens are necessary. Estrogens improve epithelial barriers and reduce intestinal permeability (87), preventing chronic mucosal inflammation in animals and humans (88).

\section{Inflammation}

Estrogens play an important role in the inflammatory response by regulating development, proliferation, migration, and apoptosis of immune cells (89). Lymphocytes have been shown to express estrogen receptors (ER $\alpha$ and $E R \beta$ ), but the expression levels of both receptors vary among cell types. $\mathrm{CD} 4+\mathrm{T}$-lymphocytes express ER $\alpha$ whereas B-lymphocytes express ER $\beta$ (90). In contrast, CD8 + T-lymphocytes express both receptors at low but equivalent levels (90). Regardless of subcellular differences, estrogens appear to exert a suppressive effect on both B- and T-lymphopoiesis. In support, B-lymphocyte formation is selectively reduced with estradiol treatment (91), and ovariectomy results in increased B-lymphopoiesis $(92,93)$. In addition to the inhibitory effect on lymphopoiesis, estradiol has been shown to influence $\mathrm{T}$ helper (Th) responses; inhibit the production of Th1 cytokines such as IL-12, TNF- $\alpha$, and IFN- $\gamma$; and stimulate Th2 anti-inflammatory cytokine production such as IL-10, IL-4, and TGF- $\beta$ (94). Estradiol has also been shown to modulate the main activities (maturation, differentiation, and migration) of myeloid cells, including monocytes, macrophages, and dendritic cells (95-98). Thus, estradiol has an important impact on immune cells and affects both the innate and the adaptive immune systems, which may account for its contribution in diseases associated with immune disorder.

\section{ESTROGEN AND ESTROGEN RECEPTORS IN THE GUT}

In an effort to identify extra-gonadal sites of de novo estradiol synthesis, we generated a double transgenic mouse line in which a transgenic aromatase (cyp19) promoter induces the expression of a red fluorescent protein (RFP) (un-published). In this animal, RFP signal is strongly expressed in the Peyer's patch $(\mathrm{Pp})$, a secondary lymphoid organ in the intestine. Pp have an organizational structure similar to lymph nodes consisting of multiple follicles and interfollicular areas. A follicle is made of a germinal center that is filled with proliferating B-lymphocytes, follicular dendritic cells, and macrophages; the interfollicular area is populated with T-lymphocytes as well as B-lymphocytes, macrophages, and dendritic cells. As part of the gut-associated lymphoid tissue, $\mathrm{Pp}$ are known as inductive sites of intestinal immune responses (99). The induction process in the $\mathrm{Pp}$ starts with sensing antigens or microbes in the gut lumen by M-cells located in a monolayer of specialized intestinal epithelial cells known as the follicle-associated epithelium. M-cells transport antigens to antigen-presenting cells, specifically dendritic cells (DCs), within the underlying sub-epithelial dome through transcytosis. Dendritic cells then further present antigens to $\mathrm{T}$-and B-lymphocytes, triggering priming and proliferation of lymphocytes to complete the immune response. A well-known effect of the Pp's induction function is generating antigenspecific intestinal IgA responses, which is critical for maintaining host-microbiota interaction, generating immune tolerance, and preventing infection (100-102). Interestingly, estrogens plays a significant role in the gastrointestinal tract. In this section, we will describe some of the lesser known roles for estrogen in the gastrointestinal system.

Napoleon Bonaparte was not aware of the true importance of his words when he said "An army marches on its stomach." Technically, an army marches on its intestines. The gastrointestinal tract (GIT) is a unique environment colonized by a remarkable variety of bacteria as well as other organisms including fungi and viruses. This superorganism, the microbiome, is not a simple spectator in biological processes but is an active component of the biochemical and metabolic health of the host (103). The microbiome is capable of digesting large molecules into simpler ones that can be efficiently reabsorbed by the host. The importance of a healthy microbiome has been well published (104-108), and multiple pathologies have been correlated with poor diversity of the microbiome, including irritable bowel (IBS) (109), osteoporosis $(110,111)$, and gluten intolerance (112). Therefore, controlling the microbiome is paramount to maintaining an optimally functioning GIT. The mucosal epithelium is perfectly adapted to monitor both microbial and nutrient composition. The release of antimicrobial peptides (113) or anti-inflammatory molecules maintains the optimal microbial ecology depending on the current GIT contents.

\section{Appetite}

Researchers have noted a correlation between estradiol levels and appetite. Food intake is significantly decreased during the preovulatory period when estradiol levels are increasing (114). These actions are attributed to estradiol inhibiting appetite indirectly through cannabinoid receptors (115). Further, blocking estrogen receptors with $\mathrm{ICl} 182,270$ ablates any action of estradiol on appetite (115). What is more interesting is that appetite is influenced by the microbiome present in the GIT. Bacterial peptides signal hunger or satiation $(113,116)$; in essence, the bacteria control our desire to eat. Locally synthesized estrogen produced in response to microbiome composition in turn may influence immune responses, bringing us back to control of microbiome composition.

Immune function. Estrogenic compounds in the gut lumen suppress immune function through targeted apoptosis and inhibition of cell proliferation in the germinal centers of ileal $P p$ (117). The Pp are important in generating protective immune responses to pathogens through both innate and cell medicated 
responses (117) and are also key in tolerizing the host to food antigens. The mucosal surfaces of the gut must maintain homeostasis, allowing sufficient function of $\mathrm{Pp}$ to prevent immune responses to food antigens yet not responding prolifically to commensal bacteria in the gut. Abnormal Pp function through estrogenic compounds is responsible for initializing autoimmune responses and impaired innate responses. Again, we see the constituents of the gut signaling control of the microbiome composition. This leads into the next topic of estrogens and cancer.

\section{Cancer}

The small intestine is the main absorptive area of the gastrointestinal tract. To maximize absorption, the epithelial layer is covered with invaginations or crypts of Lieberkühn and exists as a sheet of single cells. These cells are prone to injury and are therefore replaced every 3-5 days (118). To facilitate this replacement, the base of the crypts is populated with stem cells that differentiate into the mature epithelium as they migrate towards the crest of the crypt. ER $\alpha$ and ER $\beta$ are both expressed in the crypt cells. However, they are distributed such that ER $\alpha$ is predominantly expressed in the cells at the base of crypts and ER $\beta$ is expressed in the cells towards the crest. ER $\alpha$ signaling stimulates proliferation (119) and ER $\beta$ signaling opposes this action $(120,121)$, and the net signaling from the two receptors controls proliferation. To further support the role of estrogen receptors in tumor development, ER $\beta$-deficient mice demonstrate a hyper-proliferation of the colonic epithelium with progression to colon carcinoma (87, 122). More than 30 years ago, it was established that there is an associative risk between reduced estrogen levels and colorectal cancer in menopausal women (123) and that hormone (estrogen) replacement therapy reduces the incidence of colorectal cancer (124). Recent literature on estrogen and colorectal cancer confirms an anti-tumorigenic role for estrogen signaling in the gut due to preferential ER $\beta$ signaling (125).

However, estrogen in the gut is not always good. A recent review by Kwa et al. (103) associated the "estrobolome" (126), bacteria with the capacity to metabolize estrogens, with level of risk for breast cancer. A phylogenetic diverse microbiome favors metabolism of conjugated estrogens. Once metabolized, the free estrogens are more easily reabsorbed increasing systemic estrogen levels. Increased circulating estrogens levels increases relative risk for hormone dependent malignancies such as breast cancer. As described above, our recent unpublished work has demonstrated that not only are Pp able to respond to estrogens, but they are also a significant site of estradiol synthesis. Thus, $\mathrm{Pp}$ are able to monitor the bacterial diversity of the gut lumen and secrete estradiol. This estradiol then regulates immune responses locally and ultimately alters the diversity of the microbiome.

\section{CONCLUSION}

In conclusion, although estradiol is best recognized as sex hormone that regulates the development and function of reproductive hormone across the entire mammalian species, ever-growing evidence demonstrates its multi-faceted nature in exerting its role in non-reproductive organs and systems under normal as well as pathological conditions. It will be exciting to see what other functions estradiol may play in local tissues and from where the hormone is supplied to those sites.

\section{ACKNOWLEDGEMENTS}

This work was supported by the USDA National Institute of Food and Agriculture, Hatch project (1009826).

\section{REFERENCES}

1. Hess RA, Bunick D and Lee KH (1997) A role for oestrogens in the male reproductive system. Nature 390, 509-512

2. Simpson E, Rubin G and Clyne C (1999) Local estrogen biosynthesis in males and females. Endocr Relat Cancer $6,131-137$

3. Simpson ER (2003) Sources of estrogen and their importance. J Steroid Biochem Mol Biol 86, 225-230

4. Nelson LR and Bulun SE (2001) Estrogen production and action. J Am Acad Dermatol 45, S116-S124

5. Hemsell DL, Grodin JM, Brenner PF, Siiteri PK and MacDonald PC (1974) Plasma precursors of estrogen. II. Correlation of the extent of conversion of plasma androstenedione to estrone with age. J Clin Endocrinol Metab 38, 476-479

6. Labrie F, Bélanger A, Luu-The $V$ et al (1998) DHEA and the intracrine formation of androgens and estrogens in peripheral target tissues: its role during aging. Steroids 63, 322-328

7. Ishunina TA, van Beurden D, van der Meulen $G$ et al (2005) Diminished aromatase immunoreactivity in the hypothalamus, but not in the basal forebrain nuclei in Alzheimer's disease. Neurobiol Aging 26, 173-194

8. Azcoitia I, Sierra A, Veiga S and Garcia-Segura LM (2003) Aromatase expression by reactive astroglia is neuroprotective. Ann N Y Acad Sci 1007, 298-305

9. Balthazart J, Foidart A, Surlemont C and Harada N (1991) Distribution of aromatase-immunoreactive cells in the mouse forebrain. Cell Tissue Res 263, 71-79

10. Yague JG, Muñoz A, de Monasterio-Schrader P, Defelipe J, Garcia-Segura LM and Azcoitia I (2006) Aromatase expression in the human temporal cortex. Neuroscience $138,389-401$

11. Wehrenberg U, Prange-Kiel J and Rune GM (2001) Steroidogenic factor- 1 expression in marmoset and rat hippocampus: co-localization with StAR and aromatase. J Neurochem 76, 1879-1886

12. Yague JG, Wang AC, Janssen WG et al (2008) Aromatase distribution in the monkey temporal neocortex and hippocampus. Brain Res 1209, 115-127 
13. Cleland WH, Mendelson CR and Simpson ER (1983) Aromatase activity of membrane fractions of human adipose tissue stromal cells and adipocytes. Endocrinology $113,2155-2160$

14. Bulun SE, Price TM, Aitken J, Mahendroo MS and Simpson ER (1993) A link between breast cancer and local estrogen biosynthesis suggested by quantification of breast adipose tissue aromatase cytochrome P450 transcripts using competitive polymerase chain reaction after reverse transcription. J Clin Endocrinol Metab 77, $1622-1628$

15. Simpson ER, Zhao Y, Agarwal VR et al (1997) Aromatase expression in health and disease. Recent Prog Horm Res $52,185-213$

16. Roselli CE and Resko JA (2001) Cytochrome P450 aromatase (CYP19) in the non-human primate brain: distribution, regulation, and functional significance. J Steroid Biochem Mol Biol 79, 247-253

17. Enjuanes A, Garcia-Giralt N, Supervia A et al (2003) Regulation of CYP19 gene expression in primary human osteoblasts: effects of vitamin D and other treatments. Eur J Endocrinol 148, 519-526

18. Watanabe $M$, Simpson ER, Pathirage N, Nakajin S and Clyne CD (2004) Aromatase expression in the human fetal osteoblastic cell line SV-HFO. J Mol Endocrinol 32, 533-545

19. Janssen JM, Bland R, Hewison M et al (1999) Estradiol formation by human osteoblasts via multiple pathways: relation with osteoblast function. J Cell Biochem 75, 528-537

20. Castagnetta LA, Agostara B, Montalto G et al (2003) Local estrogen formation by nontumoral, cirrhotic, and malignant human liver tissues and cells. Cancer Res 63, 5041-5045

21. Hata $S$, Miki $Y$, Saito $R$, Ishida $K$, Watanabe $M$ and Sasano H (2013) Aromatase in human liver and its diseases. Cancer Med 2, 305-315

22. Robic A, Feve K, Louveau I and Riquet J (2016) Prunier A Exploration of steroidogenesis-related genes in testes, ovaries, adrenals, liver and adipose tissue in pigs. Anim Sci J 87, 1041-1047

23. Nicol MR, Papacleovoulou G, Evans DB et al (2009) Estrogen biosynthesis in human $\mathrm{H} 295$ adrenocortical carcinoma cells. Mol Cell Endocrinol 300, 115-120

24. Zhou Y, Kang J, Chen D, Han N and Ma H (2015) Ample Evidence: Dehydroepiandrosterone (DHEA) Conversion into Activated Steroid Hormones Occurs in Adrenal and Ovary in Female Rat. PLoS One 10, e0124511

25. Ueyama T, Shirasawa N, Numazawa M et al (2002) Gastric parietal cells: potent endocrine role in secreting estrogen as a possible regulator of gastro-hepatic axis. Endocrinology 143, 3162-3170

26. Leshin M, Baron J, George FW and Wilson JD (1981) Increased estrogen formation and aromatase activity in fibroblasts cultured from the skin of chickens with the Henny feathering trait. J Biol Chem 256, 4341-4344

27. Pomari E, Dalla Valle L, Pertile $P$, Colombo $L$ and Thornton MJ (2015) Intracrine sex steroid synthesis and signaling in human epidermal keratinocytes and dermal fibroblasts. FASEB J 29, 508-524

28. Berkovitz GD, Brown TR and Fujimoto $M$ (1087) Aromatase activity in human skin fibroblasts grown in cell culture. Steroids 50, 281-295

29. Harada N, Sasano H, Murakami H, Ohkuma T, Nagura $H$ and Takagi $Y$ (1999) Localized expression of aromatase in human vascular tissues. Circ Res 84, 1285-1291

30. Bayard F, Clamens S, Meggetto F, Blaes N, Delsol G and Faye JC (1995) Estrogen synthesis, estrogen metabolism, and functional estrogen receptors in rat arterial smooth muscle cells in culture. Endocrinology 136, 1523-1529

31. Bayard F, Clamens S, Delsol G, Blaes N, Maret A and Faye JC (1995) Oestrogen synthesis, oestrogen metabolism and functional oestrogen receptors in bovine aortic endothelial cells. Ciba Found Symp 191, 122-132

32. Samy TS, Knöferl MW, Zheng R, Schwacha MG, Bland $\mathrm{KI}$ and Chaudry IH (2001) Divergent immune responses in male and female mice after trauma-hemorrhage: dimorphic alterations in $\mathrm{T}$ lymphocyte steroidogenic enzyme activities. Endocrinology 142, 3519-3529

33. Abrahám IM, Han SK, Todman MG, Korach KS and Herbison AE (2003) Estrogen receptor beta mediates rapid estrogen actions on gonadotropin-releasing hormone neurons in vivo. J Neurosci 23, 5771-5777

34. Higaki S, Takumi K, Itoh M et al (2012) Response of ERbeta and aromatase expression in the monkey hippocampal formation to ovariectomy and menopause. Neurosci Res 72, 148-154

35. Shughrue PJ, Scrimo PJ and Merchenthaler I (2000) Estrogen binding and estrogen receptor characterization (ERalpha and ERbeta) in the cholinergic neurons of the rat basal forebrain. Neuroscience 96, 41-49

36. Almey A, Milner TA and Brake WG (2016) Estrogen receptor alpha and G-protein coupled estrogen receptor 1 are localized to GABAergic neurons in the dorsal striatum. Neurosci Lett 622, 118-123

37. Xu Y, Nedungadi TP, Zhu L et al (2011) Distinct hypothalamic neurons mediate estrogenic effects on energy homeostasis and reproduction. Cell Metab 14, 453-465

38. Cooke PS and Naaz A (2004) Role of estrogens in adipocyte development and function. Exp Biol Med (Maywood) 229, 1127-1135

39. Davis KE, Carstens EJ, Irani BG, Gent LM, Hahner LM and Clegg DJ (2014) Sexually dimorphic role of G protein- coupled estrogen receptor (GPER) in modulating energy homeostasis. Horm Behav 66, 196-207

40. Dieudonné $M N$, Leneveu MC, Giudicelli $Y$ and Pecquery R (2004) Evidence for functional estrogen receptors alpha and beta in human adipose cells: regional specificities and regulation by estrogens. Am J Physiol Cell Physiol 286, C655-C661

41. Sjögren K, Lagerquist M, Moverare-Skrtic S et al (2009) Elevated aromatase expression in osteoblasts leads to increased bone mass without systemic adverse effects. J Bone Miner Res 24, 1263-1270

42. Martin-Millan M, Almeida M, Ambrogini E et al (2010) The estrogen receptor-alpha in osteoclasts mediates the protective effects of estrogens on cancellous but not cortical bone. Mol Endocrinol 24, 323-334 
43. Määttä JA, Büki KG, Gu G et al (2013) Inactivation of estrogen receptor alpha in bone-forming cells induces bone loss in female mice. FASEB J 27, 478-488

44. Crusodé de Souza M, Sasso-Cerri E and Cerri PS (2009) Immunohistochemical detection of estrogen receptor beta in alveolar bone cells of estradiol-treated female rats: possible direct action of estrogen on osteoclast life span. J Anat 215, 673-681

45. Braidman IP, Hainey L, Batra G, Selby PL, Saunders PT and Hoyland JA (2001) Localization of estrogen receptor beta protein expression in adult human bone. J Bone Miner Res 16, 214-220

46. Bord S, Horner A, Beavan S and Compston J (2001) Estrogen receptors alpha and beta are differentially expressed in developing human bone. J Clin Endocrinol Metab 86, 2309-2314

47. Karas RH, Patterson BL and Mendelsohn ME (1994) Human vascular smooth muscle cells contain functional estrogen receptor. Circulation 89, 1943-1950

48. Russell KS, Haynes MP, Sinha D, Clerisme E and Bender JR (2000) Human vascular endothelial cells contain membrane binding sites for estradiol, which mediate rapid intracellular signaling. Proc Natl Acad Sci U S A 97, 5930-5935

49. Broughton BR, Miller AA and Sobey CG (2010) Endothelium-dependent relaxation by $\mathrm{G}$ protein-coupled receptor 30 agonists in rat carotid arteries. Am J Physiol Heart Circ Physiol 298, H1055-1061

50. Chakrabarti S and Davidge ST (2009) High glucoseinduced oxidative stress alters estrogen effects on ERalpha and ERbeta in human endothelial cells: reversal by AMPK activator. J Steroid Biochem Mol Biol 117, 99-106

51. Campbell-Thompson M, Reyher KK and Wilkinson LB (2001) Immunolocalization of estrogen receptor alpha and beta in gastric epithelium and enteric neurons. J Endocrinol 171, 65-73

52. Gaudet HM, Cheng SB, Christensen EM and Filardo EJ (2015) The G-protein coupled estrogen receptor, GPER: The inside and inside-out story. Mol Cell Endocrinol 418, 207-219

53. Thornton MJ, Taylor AH, Mulligan K et al (2003) Oestrogen receptor beta is the predominant oestrogen receptor in human scalp skin. Exp Dermatol 12, 181-190

54. El Safoury O, Rashid L and Ibrahim M (2010) A study of androgen and estrogen receptors alpha, beta in skin tags. Indian I Dermatol 55, 20-24

55. Cesinaro AM, Roncati L and Maiorana A (2010) Estrogen receptor alpha overexpression in multinucleate cell angiohistiocytoma: new insights into the pathogenesis of a reactive process. Am J Dermatopathol 32, 655-659

56. Trejter $M$, Jopek K, Celichowski P, Tyczewska $M$, Malendowicz LK and Rucinski M (2015) Expression of estrogen, estrogen related and androgen receptors in adrenal cortex of intact adult male and female rats. Folia Histochem Cytobiol 53, 133-144

57. Velders $M$, Schleipen $B$, Fritzemeier $\mathrm{KH}$, Zierau $\mathrm{O}$ and Diel P (2012) Selective estrogen receptor-beta activation stimulates skeletal muscle growth and regeneration. FASEB J 26, 1909-1920
58. Potier M, Elliot SJ, Tack I et al (2001) Expression and regulation of estrogen receptors in mesangial cells: influence on matrix metalloproteinase-9. J Am Soc Nephrol 12, 241-251

59. Le May C, Chu K, Hu M et al (2006) Estrogens protect pancreatic beta-cells from apoptosis and prevent insulin-deficient diabetes mellitus in mice. Proc Natl Acad Sci U S A 103, 9232-9237

60. Liu S, Le May C, Wong WP et al (2009) Importance of extranuclear estrogen receptor-alpha and membrane $\mathrm{G}$ protein-coupled estrogen receptor in pancreatic islet survival. Diabetes 58, 2292-2302

61. Gao H, Bryzgalova G, Hedman E et al (2006) Long-term administration of estradiol decreases expression of hepatic lipogenic genes and improves insulin sensitivity in ob/ob mice: a possible mechanism is through direct regulation of signal transducer and activator of transcription 3. Mol Endocrinol 20, 1287-1299

62. Reue K and Dwyer JR (2009) Lipin proteins and metabolic homeostasis. J Lipid Res 50, S109-S114

63. Miller WR (1991) Aromatase activity in breast tissue. J Steroid Biochem Mol Biol 39, 783-790

64. Sasano H, Uzuki M, Sawai T et al (1997) Aromatase in human bone tissue. J Bone Miner Res 12, 1416-1423

65. Shozu M and Simpson ER (1998) Aromatase expression of human osteoblast-like cells. Mol Cell Endocrinol 139, 117-129

66. Zhong M, Carney DH, Boyan BD and Schwartz Z (2011) 17 beta-Estradiol regulates rat growth plate chondrocyte apoptosis through a mitochondrial pathway not involving nitric oxide or MAPKs. Endocrinology 152, 82-92

67. Slominski A and Wortsman J (2000) Neuroendocrinology of the skin. Endocr Rev 21, 457-487

68. Brincat MP (2000) Hormone replacement therapy and the skin. Maturitas 35, 107-117

69. Harada N (1992) A unique aromatase (P-450AROM) mRNA formed by alternative use of tissue-specific exons 1 in human skin fibroblasts. Biochem Biophys Res Commun 189, 1001-1007

70. Emoto N, Ling $N$ and Baird A (1991) Growth factor-mediated regulation of aromatase activity in human skin fibroblasts. Proc Soc Exp Biol Med 196, 351-358

71. Barros RP and Gustafsson JA (2011) Estrogen receptors and the metabolic network. Cell Metab 14, 289-299

72. Parthasarathy C, Renuka VN and Balasubramanian K (2009) Sex steroids enhance insulin receptors and glucose oxidation in Chang liver cells. Clin Chim Acta 399, 49-53

73. Klair JS, Yang JD, Abdelmalek MF et al (2016) A longer duration of estrogen deficiency increases fibrosis risk among postmenopausal women with nonalcoholic fatty liver disease. Hepatology 64, 85-91

74. lavarone M, Lampertico P, Seletti C et al (2003) The clinical and pathogenetic significance of estrogen receptorbeta expression in chronic liver diseases and liver carcinoma. Cancer 98, 529-534

75. Marzioni M, Torrice A, Saccomanno S et al (2012) An oestrogen receptor beta-selective agonist exerts antineoplastic effects in experimental intrahepatic cholangiocarcinoma. Dig Liver Dis 44, 134-142 
76. Colciago A, Celotti F, Pravettoni A, Mornati O, Martini L and Negri-Cesi P (2005) Dimorphic expression of testosterone metabolizing enzymes in the hypothalamic area of developing rats. Brain Res Dev Brain Res 155, 107-116

77. Rettberg JR, Yao J and Brinton RD (2014) Estrogen: a master regulator of bioenergetic systems in the brain and body. Front Neuroendocrinol 35, 8-30

78. Kaludjerovic J and Ward WE (2012) Ward, The Interplay between Estrogen and Fetal Adrenal Cortex. J Nutr Metab 2012, 837901

79. Alonso-Magdalena $\mathrm{P}$, Ropero $\mathrm{AB}$, Carrera MP et al (2008) Pancreatic insulin content regulation by the estrogen receptor ER alpha. PLoS One 3, e2069

80. Yuchi Y, Cai Y, Legein B et al (2015) Estrogen Receptor alpha Regulates beta-Cell Formation During Pancreas Development and Following Injury. Diabetes 64, 3218-3228

81. Pedram A, Razandi M, O'Mahony F, Lubahn D and Levin ER (2010) Estrogen receptor-beta prevents cardiac fibrosis. Mol Endocrinol 24, 2152-2165

82. Novensà L, Novella $S$, Medina $P$ et al (2011) Aging negatively affects estrogens-mediated effects on nitric oxide bioavailability by shifting ERalpha/ERbeta balance in female mice. PLoS One 6, e25335

83. Prossnitz ER and Maggiolini M (2009) Mechanisms of estrogen signaling and gene expression via GPR30. Mol Cell Endocrinol 308, 32-38

84. Lowe DA, Baltgalvis KA and Greising SM (2010) Mechanisms behind estrogen's beneficial effect on muscle strength in females. Exerc Sport Sci Rev 38, 61-67

85. Enns DL and Tiidus PM (2010) The influence of estrogen on skeletal muscle: sex matters. Sports Med 40, 41-58

86. Antus B, Hamar P, Kokeny G et al (2003) Estradiol is nephroprotective in the rat remnant kidney. Nephrol Dial Transplant 18, 54-61

87. Wada-Hiraike $\mathrm{O}$, Imamov $\mathrm{O}$, Hiraike $\mathrm{H}$ et al (2006) Role of estrogen receptor beta in colonic epithelium. Proc Natl Acad Sci U S A 103, 2959-2964

88. Shen L and Turner JR (2006) Role of epithelial cells in initiation and propagation of intestinal inflammation. Eliminating the static: tight junction dynamics exposed. Am J Physiol Gastrointest Liver Physiol 290, G577-G582

89. Straub RH (2007) The complex role of estrogens in inflammation. Endocr Rev 28, 521-574

90. Phiel KL, Henderson RA, Adelman SJ and Elloso MM (2005) Differential estrogen receptor gene expression in human peripheral blood mononuclear cell populations. Immunol Lett 97, 107-113

91. Kouro T, Medina KL, Oritani K and Kincade PW (2001) Characteristics of early murine B-lymphocyte precursors and their direct sensitivity to negative regulators. Blood 97, 2708-2715

92. Masuzawa T, Miyaura C, Onoe $Y$ et al (1994) Estrogen deficiency stimulates B lymphopoiesis in mouse bone marrow. J Clin Invest 94, 1090-1097

93. Wilson CA, Mrose SA and Thomas DW (1995) Enhanced production of B lymphocytes after castration. Blood 85, 1535-1539
94. Salem ML (2004) Estrogen, a double-edged sword: modulation of $\mathrm{TH} 1$ - and $\mathrm{TH} 2$-mediated inflammations by differential regulation of $\mathrm{TH} 1 / \mathrm{TH} 2$ cytokine production. Curr Drug Targets Inflamm Allergy 3, 97-104

95. Härkönen PL and Väänänen HK (2006) Monocytemacrophage system as a target for estrogen and selective estrogen receptor modulators. Ann N Y Acad Sci 1089, 218-227

96. Komi J and Lassila O (2000) Nonsteroidal anti-estrogens inhibit the functional differentiation of human monocytederived dendritic cells. Blood 95, 2875-2882

97. Mao A, Paharkova-Vatchkova V, Hardy J, Miller MM and Kovats S (2005) Estrogen selectively promotes the differentiation of dendritic cells with characteristics of Langerhans cells. J Immunol 175, 5146-5151

98. Mor G, Sapi E, Abrahams VM et al (2003) Interaction of the estrogen receptors with the Fas ligand promoter in human monocytes. J Immunol 170, 114-122

99. Jung C, Hugot JP and Barreau F (2010) Peyer's Patches: The Immune Sensors of the Intestine. Int J Inflam 2010, 823710

100. Lycke NY and Bemark M (2012) The role of Peyer's patches in synchronizing gut IgA responses. Front Immunol 3, 329

101. Mkaddem SB, Christou I, Rossato E, Berthelot L, Lehuen A and Monteiro RC (2014) IgA, IgA receptors, and their anti-inflammatory properties. Curr Top Microbiol Immunol 382, 221-235

102. Singh K, Chang C and Gershwin ME (2014) IgA deficiency and autoimmunity. Autoimmun Rev 13, 163-177

103. Kwa M, Plottel CS, Blaser MJ and Adams S (2016) The Intestinal Microbiome and Estrogen Receptor-Positive Female Breast Cancer. J Natl Cancer Inst 108

104. Relman DA (2016) Gut microbiota: How to build healthy growth-promoting gut communities. Nat Rev Gastroenterol Hepatol 13, 379-380

105. Wischmeyer PE, McDonald D and Knight R (2016) Role of the microbiome, probiotics, and 'dysbiosis therapy' in critical illness. Curr Opin Crit Care 22, 347-353

106. Nishijima S, Suda W, Oshima K et al (2016) The gut microbiome of healthy Japanese and its microbial and functional uniqueness. DNA Res 23, 125-133

107. Highet AR, Berry AM, Bettelheim KA and Goldwater PN (2014) Gut microbiome in sudden infant death syndrome (SIDS) differs from that in healthy comparison babies and offers an explanation for the risk factor of prone position. Int J Med Microbiol 304, 735-741

108. Tuddenham S and Sears CL (2015) The intestinal microbiome and health. Curr Opin Infect Dis 28 464-470

109. Fourie NH, Wang D, Abey SK et al (2016) The microbiome of the oral mucosa in irritable bowel syndrome. Gut Microbes 2016, 1-16

110. Hernandez CJ, Guss JD, Luna M and Goldring SR (2016) Links Between the Microbiome and Bone. J Bone Miner Res [Epub ahead of print]

111. Weaver CM (2015) Diet, gut microbiome, and bone health. Curr Osteoporos Rep 13, 125-130

112. Fernandez-Feo M, Wei G, Blumenkranz G et al (2013) The cultivable human oral gluten-degrading microbiome 
and its potential implications in coeliac disease and gluten sensitivity. Clin Microbiol Infect 19, E386-E394

113. Zhao Z and Sakai T (2008) Characteristic features of ghrelin cells in the gastrointestinal tract and the regulation of stomach ghrelin expression and production. World J Gastroenterol 14, 6306-6311

114. Lyons PM, Truswell AS, Mira M, Vizzard J and Abraham SF (1989) Reduction of food intake in the ovulatory phase of the menstrual cycle. Am J Clin Nutr 49, 1164-1168

115. Mela V, Vargas A, Meza C, Kachani M and Wagner EJ (2016) Modulatory influences of estradiol and other anorexigenic hormones on metabotropic, Gi/o-coupled receptor function in the hypothalamic control of energy homeostasis. J Steroid Biochem Mol Biol 160, 15-26

116. Blaut M (2015) Gut microbiota and energy balance: role in obesity. Proc Nutr Soc 74, 227-234

117. Obremski K and Poniatowska-Broniek G (2015) Zearalenone induces apoptosis and inhibits proliferation in porcine ileal Peyer's patch lymphocytes. Pol J Vet Sci $18,153-161$

118. Matthews J, Wihlén $B$, Tujague $M$, Wan J, Ström A and Gustafsson JA (2006) Estrogen receptor (ER) beta modulates ERalpha-mediated transcriptional activation by altering the recruitment of c-Fos and c-Jun to estrogen-responsive promoters. Mol Endocrinol 20, 534-
543

119. Matthews J and Gustafsson JA (2003) Estrogen signaling: a subtle balance between ER alpha and ER beta. Mol Interv 3, 281-292

120. Matthews J and Gustafsson JA (2006) Estrogen receptor and aryl hydrocarbon receptor signaling pathways. Nucl Recept Signal 4, e016

121. Liu MM, Albanese C, Anderson CM et al (2002) Opposing action of estrogen receptors alpha and beta on cyclin D1 gene expression. J Biol Chem 277, 2435324360

122. D'Errico I and Moschetta A (2008) Nuclear receptors, intestinal architecture and colon cancer: an intriguing link. Cell Mol Life Sci 65, 1523-1543

123. Butcher D, Hassanein K, Dudgeon M, Rhodes J and Holmes FF (1985) Female gender is a major determinant of changing subsite distribution of colorectal cancer with age. Cancer 56, 714-716

124. Chlebowski RT, Wactawski-Wende J, Ritenbaugh C et al (2004) Estrogen plus progestin and colorectal cancer in postmenopausal women. N Engl J Med 350, 991-1004

125. Caiazza F, Ryan EJ, Doherty G, Winter DC and Sheahan $\mathrm{K}$ (2015) Estrogen receptors and their implications in colorectal carcinogenesis. Front Oncol 5, 19

126. Plottel CS and Blaser MJ (2011) Microbiome and malignancy. Cell Host Microbe 10, 324-335 